\title{
Schwannoma of the Median Nerve at the Wrist- A Case Report and Review of Literature
}

\author{
Damián Gómez Hernández ${ }^{1 *}$, Ricardo Monreal González ${ }^{2}$, Javier Martínez Mesa ${ }^{1}$, Eva Tejerina González ${ }^{1}$ and \\ Elizabeth Rivero Rabilero ${ }^{1}$ \\ ${ }^{1}$ Hospital Universitario Madrid Torrelodones, España \\ ${ }^{2}$ Centro Médico MEDEX, Perú
}

Submission: February 06, 2017; Published: February 15, 2017

*Corresponding author: SDamián Gómez Hernández, Hospital Universitario Madrid Torrelodones, Torrelodones, Madrid, España,

Email: daimondshoulder@yahoo.com

\begin{abstract}
Benign tumours involving peripheral nerves of the upper extremity are uncommon. Schwannomas also known as neurolemmas are usually originated from Schwann cells located in the peripheral nerve sheaths. It is generally presented as an asymptomatic mass and its slow evolution remain an essential factor in diagnosis delays. Tumors with a long evolution and relatively large dimensions can undergo degenerative changes such as cyst formation, calcification, hemorrhage and fibrosis and are described as ancient schwannomas which can be misdiagnosed as sarcomas due to specific imaging and histologic findings.

We report a rare case diagnosed as ancient schwannoma of the median nerve in a 70-year-old male. We describe the clinical presentation, the specific imaging, histology, surgical findings and functional outcome. This tumor has a good prognosis with a low recurrence rate and potential for malignant transformation. Surgical removal is usually curative.
\end{abstract}

Keywords: Ancient schwannoma; Median nerve; peripheral nerve sheath tumors; Neurilimoma

\section{Introduction}

Peripheral nerve tumors are uncommon lesions categorized into primary neuronal, nerve sheath, and non-neuronal neoplasm. Nerve sheath tumors are the most common. Schwannoma, also known as neurilemoma, is a benign soft tissue tumour arising from the Schwann cells of the nerve sheath derived from the neural crest [1,2] and usually affects patients aged 20-50 years without race or sex predilection and accounts for approximately $5 \%$ of all benign soft tissue tumors [3].

Solitary schwannoma is a slow-growing tumor and it is often found incidentally as a painless mass for years before the onset of pain and neurological symptoms caused by compressing surrounding tissues and peripheral nerves. Tumors with a long evolution and relatively large dimensions can undergo degenerative changes such as cyst formation, calcification, hemorrhage and fibrosis and are described as ancient schwannomas [4] which can be misdiagnosed as sarcomas due to specific imaging and histologic findings. We report on a very rare case diagnosed as ancient schwannoma of the median nerve. We describe the clinical presentation, the specific imaging, histology, surgical findings and functional outcome.

\section{Case Report}

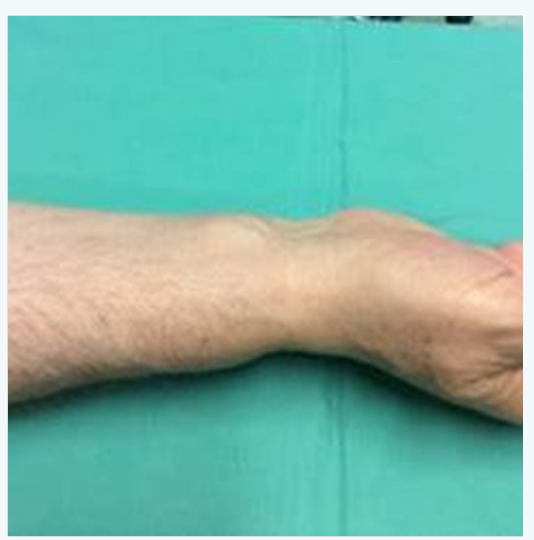

Figure 1: Swelling on the volar side of the right wrist with paresthesia in the corresponding innervation of the median nerve.

A 70 years old man presented with a painless swelling in the volar side of the right wrist of 18 years duration with complaints of increase in size of the swelling associated with pain for the 
past two years. He complained of pain and paraesthesia in the median nerve distribution area of the right hand. The swelling (Figure 1) was mobile on the transverse axis and not on the longitudinal axis. There was loss of sensation in the distribution of the median nerve in the hand with weakness in performing her day to day activities. Percussion over the nerve produced positive Tinel's sign. An ultrasound (US) scan revealed an encapsulated, heterogeneous, solid mass, mainly hypoechogenic, with regions of increased echogenity.

A 1.5-T superconductive Magnetic Resonance Image (MRI) unit (GE Healthcare) was used to produce spin-echo images and a gadolinium-enhanced scan confirmed the presence of a wellcircumscribed and encapsulated soft tissue mass, which showed low signal intensity on the T1-weighted sequences (Figure 2a) and high signal intensity in T2 images (Figure 2b). On T1 fat suppressed images, increased gadolinium enhancement was noticed at the periphery of the mass with a non-enhancing low signal in areas of hemorrhage or degeneration. Based on the long history of the patient, and the clinical, US, and MRI features, the diagnosis of a nerve sheath tumor arising from the median nerve was supported and the patient was scheduled for excisional biopsy.

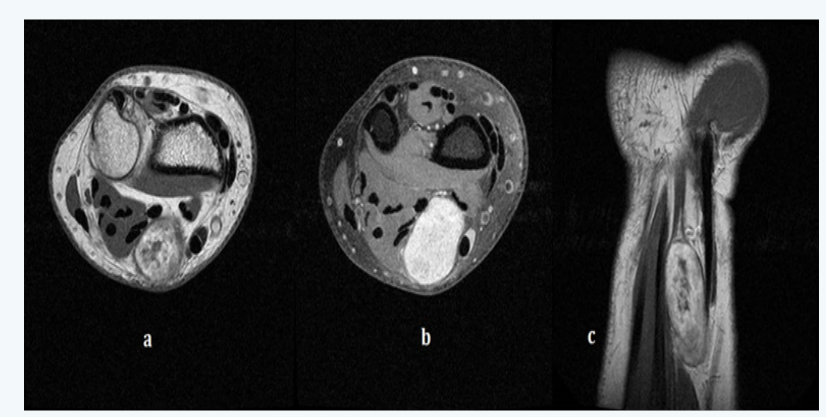

Figure 2: MRI findings: a) Axial T1-weighted MR image shows large well-circumscribed mass with isointense signal. b) Axial T2-weighted image shows the tumor as hyperintense signal. c). Sagittal TI-weighted image. Gadolinium contrast-enhanced image shows enhancement at circumference of degenerative lesion, and substantial part.

\section{Surgical procedure}

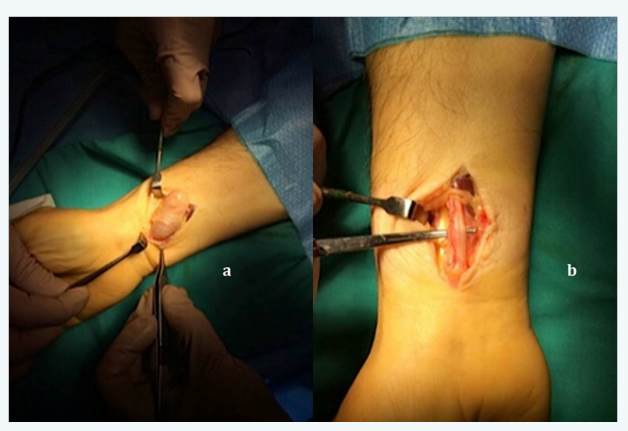

Figure 3: a) Intraoperative view of the lesion showing that the mass at the wrist was originated from the median nerve. b) After tumor excision performed under magnification the integrity of the median nerve is preserved.
The patient was taken up for surgery under general anesthesia and a longitudinal incision centered over the tumor bulk was performed. On exploration was found a $3 \mathrm{~cm}$ long well encapsulated tumor arising from the median nerve in an eccentric position to the axis of the nerve (Figure 3a). A marginal tumor excision was performed under magnification in order to preserve the median nerve (Figure $3 \mathrm{~b}$ ) and the specimen was sent for histopathological examination.

\section{Histologic examination}

Histology confirmed the presence of a well-defined neoplasm surrounded by a fibrous capsule focally connected to a displaced parent nerve. The tumor composed of fusiform cells with spindle-shaped, tapered nuclei with inconspicuous nucleoli and eosinophilic cytoplasm (Schwann cells) showed the typical biphasic pattern of Antoni A (Figure 4a) and Antoni B (Figure 4b) areas. The first one, referred to as Antoni A, was more densely cellular and consisted of Schwann cells compactly disposed in broad bundles and interlacing fascicles. In these areas some nuclei were grouped into palisaded clusters. The second one, named Antoni B, was loose-textured due to the presence of a myxoid matrix. Areas of haemorrage and perivascular hemosiderin deposition were seen, but coagulative necrosis was not observed (Figure 4c) the vessels showed typically hyalinized walls (Figure 4d). Although remarkable nuclear pleomorphism was not a feature, some cells showed larger, hyperchromatic nuclei, with occasional pseudoinclusions. Mitotic figures were not found.

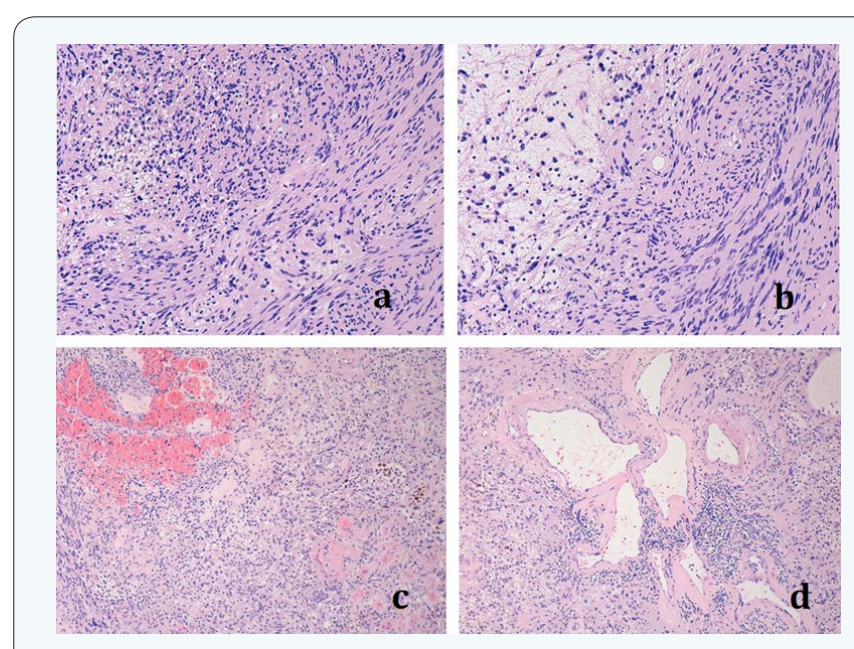

Figure 4: Typical biphasic pattern and degenerative changes: a) Antoni A area, b) Antoni B area, c) haemorrage and perivascular hemosiderin deposition, d) Hyalinized and thickened blood vessel (arrow).

Impression: median nerve tumor Schwannoma with myxoid degeneration, areas of haemorrage and perivascular hemosiderin deposition suggestive of Ancient schwannoma. No evidence of malignancy.

\section{Postoperative period}

No motor deficit was noted postoperatively and the patient 
resumed her previous activities 4 weeks after surgery. Five months after surgery, the patient was asymptomatic and without any local signs of recurrence.

\section{Discussion}

Schwannomas are common, slowly growing, and encapsulated benign nerve sheath neoplasms separated from the surrounding tissues. These tumors are soft in consistency, mobile in nature, and sometimes painless so they may be misdiagnosed as lipoma, fibroma, ganglion, or xanthoma but the present case report suggests that the combination of ultrasound and MRI findings provides features that narrow the differential diagnosis.

On pathologic analysisgenerally displays a biphasic pattern, with areas of highly ordered cellularity (Antoni type A) and less cellularareas in which a highly myxoid matrix predominates (Antoni type B). Although schwannomas of the hand and wrist are well reported [5-8], few reports of ancient schwannomas exist [9-12].

Ackerman and Taylor in 1951 [4] described ancient schwannoma with clear areas of hypo cellular tissues due to the long standing degenerative changes attributed to the growth and "aging" of the tumor hence called ancient schwannoma. An ancient schwannoma is described [13] as a benign schwannoma having severe degenerative changes that include cyst formation, calcification, hemorrhage, and marked hyalinization. Schwannomas can be asymptomatic or can produce pain, a positive Tinel's sign or a Tinel's like sensation and sensory alterations [14-16]. The slow growth pattern of benign nerve tumors, allows for adaptation of the nerve function to the pressure effects.

The mainstay treatment is complete excision, although local recurrence can occur in large and incompletely excised lesions. Malignant transformation of benign schwannomas is unusual $[17,18]$.

\section{Conclusion}

Ancient schwannoma of the median nerve is a rare peripheral nerve tumor where the combination of ultrasound and MRI findings provides features to diagnosis. Surgical resection must be approached with caution to protect nerve function and continuity and it is associated with good outcomes. The recurrence rate is low.

\section{Author's disclosure statement}

The authors report no actual or potential conflict of interest in relation to this article.

\section{References}

1. Weiss SW, Goldblum JR, Enzinger FM (2001) Benign tumors of peripheral nerves. Enzinger and Weiss's soft tissue tumors, 4th edition, Mosby, St. Louis, 1111-1208.

2. Giannini C (2005) Tumors and tumor-like conditions of peripheral nerves. Peripheral neuropathy, 4th edition, Elsevier-Saunders, Philadelphia, USA, 2585-2606.

3. Kransdorf MJ (1995) Benign soft-tissue tumors in a large referral population: distribution of specific diagnoses by age, sex, and location. AJR Am J Roentgenol 164(2): 395-402.

4. Ackerman LV, Taylor FH (1951) Neurogenous tumors within the thorax: a clinicopathological evaluation of 48 cases. Cancer 4: 669-691.

5. Ozdemir O, Ozsoy MH, Kurt C, Coskunol E, Calli I (2005) Schwannomas of the hand and wrist: long-term results and review of the literature. J Orthop Surg (Hong Kong) 13(3): 267-272.

6. Rockwell GM, Thoma A, Salama S Schwannoma of the hand and wrist. Plast Reconstr Surg 2003; 111:1227-1232.

7. Gundes H, Tosun B, Muezzinoglu B, Alici T (2004) A very large Schwannoma originating from the median nerve in carpal tunnel. J Peripher Nerv Syst 9(3): 190-192.

8. Bhatti AM, Alo GO, Power DM, Masood A, Thuse MG (2005) Lobulated schwannoma of the median nerve: pitfalls in diagnostic imaging. J Comput Assist Tomogr 29(3): 330-332.

9. Squarzina PB, Adani R, Cerofolini E, Bagni A, Caroli A (1993) Ancient schwannoma of the motor branch of the median nerve: a clinical case. Chir Organi Mov 78(1): 19-23.

10. Tadvi JS, Anand A, Humphrey A (2007) Ancient schwannoma of the middle finger. J Hand Surg 32E: 722.

11. Isobe K, Shimizu T, Akahane T, Kato H (2004) Imaging of ancient schwannoma. AJR Am J Roentgenol 183(2): 331-336.

12. Vlychou M, Dailiana ZH (2011) Ancient Schwannoma of the Hand. J Hand Surg 36(12): 2030-2033.

13. Dahl I (1977) Ancient neurilemmoma (schwannoma). Acta Pathol Microbiol Scand A 85(6): 812-818.

14. Knight DM, Birch R, Pringle J (2007) Benign solitary schwannomas: a review of 234 cases. J Bone Joint Surg Br 89(3): 382-387.

15. Ogose A, Hotta T, Morita T, Yamamura S, Hosaka N, et al. (1999) Tumors of peripheral nerves: correlation of symptoms, clinical signs, imaging features, and histologic diagnosis. Skeletal Radiol 28(4): 183-188.

16. K Malizos, V Kontogeorgakos, M Ioannou (2013) Ancient schwannoma involving the median nerve: a case report and review of the literature. Strat Traum Limb Recon 8(1): 63-66.

17. Rekha A, Ravi A (2004) Sciatic nerve schwannoma. Int J Low Extrem Wounds 3(3): $165-167$.

18. Ozdemir O, Ozsoy MH, Kurt C, Coskunol E, Calli I (2005) Schwannomas of the hand and wrist: long-term results and review of the literature. J OrthopSurg (Hong Kong) 13: 267-272. 
This work is licensed under Creative Commons Attribution 4.0 License DOI: $10.19080 / O R O A J .2017 .04 .555648$
Your next submission with Juniper Publishers will reach you the below assets

- Quality Editorial service

- Swift Peer Review

- Reprints availability

- E-prints Service

- Manuscript Podcast for convenient understanding

- Global attainment for your research

- Manuscript accessibility in different formats

( Pdf, E-pub, Full Text, Audio)

- Unceasing customer service

Track the below URL for one-step submission https://juniperpublishers.com/online-submission.php 